\title{
Estimation of Yield Losses Due to Major Sucking Insect Pests of Bt Cotton
}

\author{
D. K. Makwana, K.A. Chudasama and T.K. Balas* \\ Department of Entomology, College of Agriculture, Junagadh Agricultural University, \\ Junagadh-362 001, Gujarat, India \\ *Corresponding author
}

\begin{abstract}
A B S T R A C T
Keywords

Bt cotton, Yield losses, Sucking pests

Article Info

Accepted:

10 April 2018

Available Online:

10 May 2018

Present investigation on estimation of yield losses due to major sucking pests of the $B t$ cotton was carried out on the College Farm, College of Agriculture, Junagadh Agricultural University, Junagadh during Kharif season of the year 2011-12. The Bt hybrid cotton cultivar KDCHH-441 was grown with the plot size of $24 \mathrm{~m} \mathrm{X} 20 \mathrm{~m}$ at spacing of $120 \mathrm{~cm} \mathrm{X}$ $45 \mathrm{~cm}$. The data revealed that significantly higher seed cotton yield $2038.82 \mathrm{~kg} / \mathrm{ha}$ was recorded from protected plots, while the yield of $1312.70 \mathrm{~kg} / \mathrm{ha}$ was recorded from unprotected plots. The yield increased in protected plots over unprotected plots was 726.12 $\mathrm{kg} / \mathrm{ha}$. This showed 55.31 per cent increase in yield and 35.61 per cent avoidable loss. The result clearly indicated that by providing protection with effective pesticides against cotton sucking pests, $726.12 \mathrm{~kg} / \mathrm{ha}$ yield loss can be saved. Total avoidable yield loss could be worked out as 35.61 per cent.
\end{abstract}

\section{Introduction}

Cotton crop is known as "White gold" and is a premier commercial crop in India, which occupies only 5 per cent of the arable land and supports 60 million people having direct bearing on the country's economy. India is a unique among the cotton growing countries of the world in which four species of cotton viz., Gossypium hirsutum, G. barbadense, $G$. arboreum and $G$. herbaceum are grown commercially under diversified ecosystem. In India, it is cultivated in 110.00 million hectares with 325.00 lakh bale production and an average productivity was $503 \mathrm{~kg} / \mathrm{ha}$ during 2010-11 (Anon., 2011). India accounts for approximately 23 per cent of the world cotton area but the average productivity of cotton is markedly low at about $521 \mathrm{~kg} / \mathrm{ha}$ as compared to world average of $765 \mathrm{~kg} / \mathrm{ha}$. The major cotton growing states in India are Maharashtra, Gujarat, Andhra Pradesh, Madhya Pradesh, Punjab, Haryana, Karnataka, Rajasthan, Tamil Nadu and Orissa.

Gujarat stands the second in respect of area 26.20 million ha and the first in respect of production 106.82 lakh bale with the productivity of $693 \mathrm{~kg} / \mathrm{ha}$ during 2010-11 (Anon., 2011). The average productivity of cotton in India is lower than Brazil, China, USA and Pakistan in the world. In addition to cultivation on marginal lands and the complexities of pest management are also important. Among the different constraints 
that limit the production and productivity of cotton crop in India, the insect pests are considered to be the most serious. In India, 160 species of insect pests have been reported to attack the cotton crop right from time of germination till the final harvesting of cotton (Agarwal, 1978). The total loss due to cotton pests (jassid and bollworm complex) in north, central and south zone was estimated as 52.80, 46.53 and 47.56 per cent, respectively (Basu et al., 1990). Among the various insect pests listed above, aphid, whitefly, thrips, cotton leaf hopper or jassid and mealy bugs are the major sucking pests of cotton and limiting the profitable cultivation. Due to introduction and adoption of $B t$ hybrid cotton, the yield losses caused by bollworms become minimized. According to Butani and Jotwani (1984), A. gossypii is a polyphagous pest and cotton, tomato, brinjal, beans, potato and okra are its main hosts. Both nymphs and adults suck the cell sap and secrete honey dew, which not only attract the black ants but also favours the growth of sooty mould giving the plants a sticky and blackish appearance.

Whitefly is also a polyphagous pest found in most of the countries in tropics and sub tropics. Its main hosts are cotton, tobacco and some winter vegetables including brinjal and tomato. The infestation on these crops is sporadically severe. This pest also sucks the cell sap from the various plant parts and secretes honey dew (Butani and Jotwani, 1984). Dhawan et al., (1988) reported that $A$. biguttula biguttula is one of the most serious sucking pests of cotton in India causing reduction in yield to an extent of 20 per cent. The information on yield losses due to major sucking pests of the $B t$ cotton particularly under Junagadh condition is very scanty hence in view of the importance of sucking pests, it is necessary to have comprehensive information on these aspects. The present investigation was, therefore, carried out on the following aspect.

\section{Materials and Methods}

With a view to estimate the losses caused by major sucking pest in the $B t$ cotton, an experiment was carried out at College Farm, JAU, Junagadh during Kharif- 2011-12. The $B t$ hybrid cotton cultivar KDCHH-441 was grown with the plot size of $24 \mathrm{~m} \mathrm{X} 20 \mathrm{~m}$ at spacing of $120 \mathrm{~cm}$ x $45 \mathrm{~cm}$. All the recommended agronomical practices were followed to raise the crop.

For this purpose, two strip each of $12 \mathrm{~m}$ x $20 \mathrm{~m}$ was prepared and from each strip fifteen quadrate of size $2.5 \mathrm{~m} \times 1.5 \mathrm{~m}$ was selected randomly for the observations. From two plots one plot is unprotected which was kept free from insecticides and subjected to the natural occurrence of the sucking pests of cotton and another protected plot was protected against the major sucking insect pests damage through application of recommended insecticides viz., imidacloprid @ $0.01 \%$ and quinalphos @ $0.05 \%$ alternately at ten day interval.

\section{Observations to be recorded}

The observations on yield of treated plot $\mathrm{kg} /$ quadrate and yield of untreated plot $\mathrm{kg}$ /quadrate were recorded from each quadrate and the data was subjected to statistical analysis using CRD design.

\section{Yield and economics}

The grain yield obtained from each quadrate was converted on hectare basis and subjected to statistical analysis. The per cent increase in yield over control was calculated by using following formula:

Yield increase over control $=\frac{T-C}{C} \times 100$

Where, 
$\mathrm{T}=$ Yield of protected plot $(\mathrm{kg} / \mathrm{ha})$

$\mathrm{C}=$ Yield of unprotected plot $(\mathrm{kg} / \mathrm{ha})$

The percentage avoidable loss in yield due to sucking pests was calculated as per the formula given by (Khosla, 1977).

Percentage avoidable loss $=\frac{T-C}{T} \times 100$

Where,

$\mathrm{T}=$ Yield in the protected plot $(\mathrm{kg} / \mathrm{ha})$

$\mathrm{C}=$ Yield in the unprotected plot $(\mathrm{kg} / \mathrm{ha})$

\section{Results and Discussion}

The data on yield losses in $B t$ cotton due to sucking pests are presented in Table 1 revealed that 26.21 per cent damage was recorded in unprotected crop (untreated plots). While in protected crop (treated plots) only 7.29 per cent damage was recorded due to the sucking pests.

The data presented in Table 1 further revealed that significantly higher cotton yield 2038.82 $\mathrm{kg} / \mathrm{ha}$ was recorded from protected plots, while the yield of $1312.70 \mathrm{~kg} / \mathrm{ha}$ was recorded from unprotected plots. The yield increased in protected plots over unprotected plots was $726.12 \mathrm{~kg} / \mathrm{ha}$. This showed 55.31 per cent yield increased over control and 35.61 per cent avoidable loss.

The result clearly indicated that by providing protection with effective pesticides against cotton sucking pests, $726.12 \mathrm{~kg} / \mathrm{ha}$ yield loss can be saved. Total avoidable yield loss could be worked out as 35.61 per cent.

Table.1 Yield losses in Bt cotton crop due to sucking pests during Kharif 2011-12

\begin{tabular}{|c|c|c|c|c|c|}
\hline Treatment & Damage (\%) & $\begin{array}{c}\text { Cotton } \\
\text { Yield } \\
\text { Kg/ha }\end{array}$ & $\begin{array}{c}\text { Yield } \\
\text { Loss } \\
\text { Kg/ha }\end{array}$ & $\begin{array}{c}\text { Avoidable } \\
\text { Yield loss } \\
(\%)\end{array}$ & $\begin{array}{c}\text { Yield increased } \\
\text { Over } \\
\text { Control }(\%)\end{array}$ \\
\hline $\begin{array}{c}\text { Untreated } \\
\text { (unprotected) }\end{array}$ & $\begin{array}{c}32.37 \\
(26.21)\end{array}$ & 1312.70 & 726.12 & - & - \\
\hline $\begin{array}{c}\text { Treated } \\
\text { (Protected) }\end{array}$ & $\begin{array}{c}9.68 \\
(7.29)\end{array}$ & 2038.82 & - & 35.61 & 55.31 \\
\hline S. $E_{m} \pm$ & 1.67 & 45.57 & & & \\
\hline C.D & 4.91 & 131.99 & & & \\
\hline C.V \% & 10.71 & 11.57 & & & \\
\hline
\end{tabular}

\section{References}

Anonymous (2001-02, a). Annual Research Report, Main Cotton Research Station, Gujarat Agricultural University, Surat, pp.E-4.

Anonymous (2003-04, a). Annual Research Report, Main Cotton Research Station, Gujarat Agricultural University, Surat, pp.E-2.
Anonymous (2003-04, b). Annual Research Report, Main Cotton Research Station, Gujarat Agricultural University, Surat, pp.E-3.

Anonymous (2006). FAO Website WWW.FAO.Org.

Anonymous (2011). Crop wise area, production and productivity of Gujarat state. Directorate of Economics and Statistics, Dept. of Agriculture and cooperation, 28-29 pp. 
Attique, M. R. and Ghaffar, A. (1996). Control of early season sucking pests of cotton with seed protectant insecticides and their impact on natural enemies and yield of seed cotton. Pakistan J. Zoology, 28(3): 253-255.

Bhardwaj, S. B. and Kushwaha, K. S. (1984). Whitefly, Bemisia tabaci (Genn.) (Homoptera: Aleyrodidae) infesting tomato in Rajasthan. Bull. Ent., 25(1): 76-97.

Butani, D. K. and Jotwani, M. G. (1984). Insects In Vegetables. Periodical Export Book Agency, Delhi pp. 44-68.

Butani, D. K. and Verma, S. (1976). Insect pests of vegetables and their control-4: Lady's finger. Pesticides, 10(7): 31-37.

Chavan, S. J., Bhosle, B. B. and Bhute, N. K. (2010). Estimation of losses due to major insect-pests in desi cotton in Maharashtra. J. Cotton Res. Dev., 24(1): 95-96.

Dhavan, A. K. and Sidhu, A. S. (1986). Assessment of losses due to the attack of cotton jassid on hirsutum cotton. Indian J. Pl. Prot., 14: 45-50.

Dhawan, A. K., Sharma, M., Jindal, V. and Kumar, R. (2008). Estimation of losses due to insect pests in $B t$ cotton. Indian $\mathrm{J}$. Ecol., 35(1): 77-81.

Dhawan, A. K., Sidhu, A. S. and Simwat, G. S. (1988). Assessment of avoidable loss in cotton (Gossypium hirsutum and $G$. arboreum) due to sucking pests and boll worms. Indian J. Agric. Sci., 58(4): 290-292.

Patel, I. S. and Rote, N. B. (1995). Seasonal incidence of sucking pest complex of cotton under rainfed condition of South Gujarat. GAU Res. J., 21(1): 127-129.

Patel, K. I., Patel, J. R., Jayani, D. B., Shekh, A. M. and Patel, N. C. (1997). Effect of seasonal weather on incidence and development of major pests of okra (Abelmoschus esculentus). Ind. J. Agric. Sci., 67(5): 181-183.

Raghvani, K. L. and Talati, G.M. (1991). Relative efficacy of some dust formulations against jassids and thrips of Hybrid-4 cotton. GAU Res. J., 17(1): 132-135.

Rathod, K. S., Lavekar, R. C., Pande, A. K., Patange, N. R. and Sharma, O. P. (2003). Efficacy of imidachloprid against sucking pests of cotton. Annals Pl. Prot. Sci., 11(2): 369-370.

Satpute, N. S., Katole, S. R., Nimbalkar, S. A., Sarnaik, D. N. and Satpute, U. S. (2001). Efficacy of imidacloprid and thiamethoxam seed treatment against cotton jassid. J. Applied Zoological Res., 12(1): 88-90.

Vadodaria, M. P., Patel, C. J., Patel, R. B., Maisuria, I. M. and Patel, U. G. (2001). Imidacloprid (Gaucho), a new seed dresser against early sucking pests of cotton. GAU Res. J., 26(2): 32-38.

\section{How to cite this article:}

Makwana, D.K., K.A. Chudasama and Balas, T.K. 2018. Estimation of Yield Losses Due to Major Sucking Insect Pests of Bt Cotton. Int.J.Curr.Microbiol.App.Sci. 7(05): 956-959. doi: https://doi.org/10.20546/ijcmas.2018.705.118 